X-ray Structure Analysis Online

\title{
Crystal Structure of (2E)-3-(2-Thienyl)acrylic acid-benzene-1,2-diamine
}

\author{
Mehmet AKKurt, ${ }^{*}$ Sema Öztürk YILdIRIM, ${ }^{* \dagger}$ Nihat Şíreci, ${ }^{* *}$ Hasan KüÇÜKBAY, ${ }^{* *}$ and \\ Orhan BÜYÜKGÜNGÖR*** \\ *Department of Physics, Faculty of Arts and Sciences, Erciyes University, 38039 Kayseri, Turkey

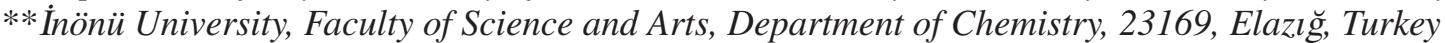 \\ ***Ondokuz, Mayls University, Department of Physics, Faculty of Arts and Science, 55139 Samsun, Turkey
}

\begin{abstract}
The title compound, (2E)-3-(2-thienyl)acrylic acid-benzene-1,2-diamine, was synthesized by the reaction of 1,2diaminobenzen and 3-(2-tienyl)acrylic acide in a dioxane solution. The compound crystallizes in the orthorhombic space group Pbcn; $a=24.610(5) \AA, b=7.588(5) \AA, c=11.289(5) \AA, V=2108.1(17) \AA^{3}$ and $Z=8$. The final $R$ value is 0.047 . The thiophene and benzene ring are each essentially planar. The benzene-1,2-diamine moity in the title compound has a rotation axis that passes through the mid point of the bonds C8-C8a and C10-C10a. The crystal packing is stabilized by intermolecular $\mathrm{N}-\mathrm{H} \cdots$ and $\mathrm{O}-\mathrm{H} \cdots \mathrm{N}$ hydrogen-bonding interactions.
\end{abstract}

(Received November 16, 2006; Accepted March 9, 2007; Published on web November 29, 2007)

Heterocyclic compounds generally show versatile pharmacological activities, such as antitumor, diuretics, fungicides, bactericides, antihelmintic, antiallergic, vasodilator, antihistaminic, anti-ulcer and local analgesic. ${ }^{1-3}$ We here report

Table 1 Crystal and experimental data

Formula: $\mathrm{C}_{7} \mathrm{H}_{6} \mathrm{O}_{2} \mathrm{~S} \cdot\left(\mathrm{C}_{6} \mathrm{H}_{8} \mathrm{~N}_{2}\right)$

Formula weight $=208.26$

Crystal system: orthorhombic

Space group: $P b c n ; Z=8$

$a=24.610(5) \AA$

$b=7.588(5) \AA$

$c=11.289(5) \AA$

$V=2108.1(17) \AA^{3}$

$D_{\mathrm{x}}=1.312 \mathrm{~g} \mathrm{~cm}^{-3}$

$\mu\left(\right.$ Mo $\left.K_{\alpha}\right)=0.28 \mathrm{~mm}^{-1}$

$T=293(2) \mathrm{K}$

Crystal size $=0.66 \times 0.52 \times 0.38 \mathrm{~mm}$

Radiation: Mo $K_{\alpha}$

$R=0.047$

$R_{\mathrm{w}}=0.147$

No. of unique data measured $=2277$

No. of observed data with $[I \geq 2 \sigma(I)]=1756$

No. of parameters $=140$

Goodness-of-fit $=1.05$

$(\Delta \rho)_{\max }=0.37 \mathrm{e}^{-3}$

$(\Delta \rho)_{\min }=-0.37 \mathrm{e}^{-3}$

Measurements: STOE IPDS 2 diffractometer

Program system: X-AREA

Structure determination: SIR97

Refinement: SHELXL97

CCDC 626235 contains the supplementary crystallographic data for this paper. These data can be obtained free of charge from The

Cambridge Crystallographic Data Centre via

www.ccdc.cam.ac.uk/data_request/cif.

$\doteqdot$ To whom correspondence should be addressed.

E-mail: ozturk@erciyes.edu.tr on the crystal structure of (2E)-3-(2-thienyl)acrylic acidbenzene-1,2-diamine, based on our studies.

A mixture of 1,2-diaminobenzene (1.08 g; $10 \mathrm{mmol})$ and 3-(2tienyl)acrylic acide $(1.54 \mathrm{~g} ; 10 \mathrm{mmol})$ in dioxane $(10 \mathrm{ml})$ was heated under reflux for $3 \mathrm{~h}$. The mixture was then cooled and the volatiles were removed by vacuo (Fig. 1). The residue was crystallized from an $\mathrm{EtOH} / \mathrm{Et}_{2} \mathrm{O}(3: 1)$ mixture. Yield: $1.86 \mathrm{~g}$, 71\%. M.p.: $391-392 \mathrm{~K}$.

${ }^{1} \mathrm{H}-\mathrm{NMR}\left(\mathrm{D}_{2} \mathrm{O}\right): \delta 6.10(\mathrm{~d}, \mathrm{HC}=, 1 \mathrm{H}), \delta 6.75(\mathrm{~m}, \mathrm{Ph}-\mathrm{H}$ and $\left.\mathrm{NH}_{2}{ }^{+1 / 2}, 9 \mathrm{H}\right), \delta 6.91(\mathrm{t}$, tienyl, $1 \mathrm{H}), \delta 7.14(\mathrm{~d}$, tienyl, $1 \mathrm{H}), \delta 7.29$

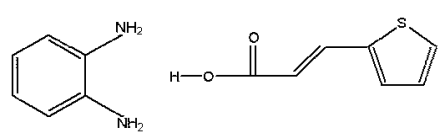

Fig. 1 Chemical scheme of the title compound.

Table 2 Final atomic coordinates and equivalent isotropic thermal displacement parameters for non-hydrogen atoms

\begin{tabular}{|c|c|c|c|c|}
\hline Atom & $x$ & $y$ & $z$ & $U_{\text {eq }}$ \\
\hline$\$ 1$ & $0.21661(2)$ & $0.32011\{9\}$ & $0.45512(5)$ & $0.0771(2)$ \\
\hline 01 & $0.42432(5)$ & $0.4007(2)$ & $0.59672(12)$ & $0.0693(5)$ \\
\hline $\mathrm{O} 2$ & $0.37829(5)$ & $0.4720(2)$ & $0.75866(12)$ & $0.0670(5)$ \\
\hline $\mathrm{cl}$ & $0.14870(10)$ & $0.3243(3)$ & $0.4744\{2\}$ & $0.0790\{8\}$ \\
\hline $\mathrm{C} 2$ & $0.13336(9)$ & $0.3688(3)$ & $0.5839(3)$ & $0.0777(7)$ \\
\hline$c 3$ & $0.17744(7)$ & $0.4042(3)$ & $0.6654\{2\}$ & $0.0660(6)$ \\
\hline $\mathrm{CA}$ & $0.22806(7)$ & $0.3830(2)$ & $0.59908(16)$ & $0.0558\langle 5\rangle$ \\
\hline$c 5$ & $0.28167(7)$ & $0.4098\langle 2\}$ & $0.64720(16)$ & $0.0564\langle 5\rangle$ \\
\hline $\mathrm{C} 6$ & $0.32852(7)$ & $0.3829(3)$ & $0.59242(17)$ & $0.0598\langle 5\rangle$ \\
\hline $\mathrm{C7}$ & $0.38095(7)$ & $0.4192(2)$ & $0.64811(15)$ & $0.0550\langle 5\rangle$ \\
\hline N1 & $0.52999(7)$ & $1.4105(2)$ & $0.14526(13)$ & $0.0552(5)$ \\
\hline $\mathrm{C} 8$ & $0.51465(11)$ & $0.9321\langle 3\rangle$ & $0.1976(4)$ & $0.0950\{12\}$ \\
\hline $\mathrm{Cg}$ & $0.52890(8)$ & $1.0881(3)$ & $0.1454(2)$ & $0.0700\langle 7\rangle$ \\
\hline $\mathrm{c10}$ & $0.51435(6)$ & $1.2470\{2\}$ & $0.19650\langle 14\rangle$ & $0.0519\{5\}$ \\
\hline
\end{tabular}

$U_{\mathrm{eq}}=(1 / 3) \Sigma_{i} \Sigma_{j} U_{i j} a_{i}^{*} a_{j}^{*}\left(\boldsymbol{a}_{i} \cdot \boldsymbol{a}_{j}\right)$. 

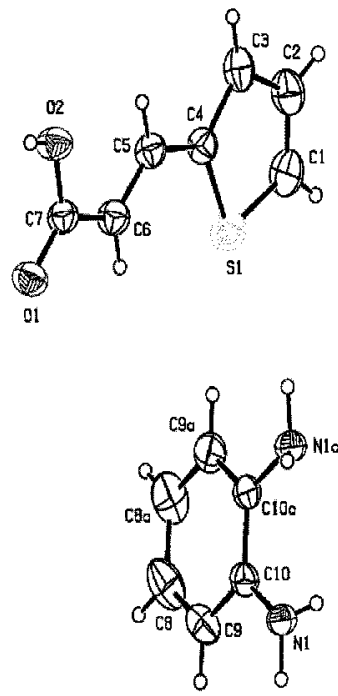

Fig. 2 ORTEP-3 view of the title compound, with the atomnumbering scheme and $30 \%$ probability displacement ellipsoids.

Table 3 Bond lengths $(\AA)$ and bond angles $\left({ }^{\circ}\right)$

\begin{tabular}{|c|c|c|c|}
\hline $\mathrm{S} 1-\mathrm{C} 1$ & $1.686(3)$ & $02-C 7$ & $1.312(2)$ \\
\hline $\mathrm{S} 1-\mathrm{C} 4$ & $1.717(2)$ & $\mathrm{N} 1-\mathrm{C} 10$ & $1.422(2)$ \\
\hline $\mathrm{O}-\mathrm{Cl}$ & $1.223(2)$ & $\mathrm{C} 1-\mathrm{C2}$ & $1.335(4)$ \\
\hline $\mathrm{C} 2-\mathrm{C} 3$ & $1.448(4)$ & $\mathrm{CB}-\mathrm{Cg}$ & $1.368(4)$ \\
\hline $\mathrm{C3}-\mathrm{CA}$ & $1.462\{3\}$ & $C 8-C 8^{i}$ & $1.386(6)$ \\
\hline $\mathrm{C} 4-\mathrm{Cs}$ & $1.441(3)$ & C9-C10 & $1.384(3)$ \\
\hline$C 5-C 6$ & $1.324(3)$ & $\mathrm{C} 10-\mathrm{C} 1 \mathrm{O}^{\mathrm{I}}$ & $1.399(2)$ \\
\hline $\mathrm{C} 6-\mathrm{c} 7$ & $1.462(3)$ & & \\
\hline $\mathrm{Cl}-\mathrm{SI}-\mathrm{CA}$ & $92.02(10)$ & $\mathrm{O} 2-\mathrm{C} 7-\mathrm{C} 6$ & $115.00(15)$ \\
\hline $\mathrm{S} 1-\mathrm{Cl}-\mathrm{C} 2$ & $113.86(18)$ & $\mathrm{O} 1-\mathrm{C} 7-\mathrm{O} 2$ & $121.99(16)$ \\
\hline $\mathrm{S} 1-\mathrm{C} 4-\mathrm{C} 3$ & $112.05(13)$ & $\mathrm{N} 1-\mathrm{C} 10-\mathrm{Cg}$ & $121.37\{16\}$ \\
\hline $\mathrm{S} 1-\mathrm{C} 4-\mathrm{C} 5$ & $123.11(13)$ & $\mathrm{N} 1-\mathrm{C} 10-\mathrm{C} 10 \underline{\mathrm{i}}$ & $119.20\{14\}$ \\
\hline $\mathrm{O} 1-\mathrm{C} 7-\mathrm{CE}$ & $123.01\langle 16\rangle$ & $\mathrm{Cl}-\mathrm{C} 2-\mathrm{C} 3$ & $115.0\langle 2\rangle$ \\
\hline $\mathrm{C} 2-\mathrm{C} 3-\mathrm{CA}$ & $107.0\{2\}$ & $\mathrm{C} 8^{2}-\mathrm{C} 8-\mathrm{Cs}$ & $120.1(2)$ \\
\hline $\mathrm{C} 3-\mathrm{C} 4-\mathrm{C5}$ & $124.85(17)$ & $\mathrm{C} 8-\mathrm{C} 9-\mathrm{C} 10$ & $120.5(2)$ \\
\hline $\mathrm{C} 4-\mathrm{C} 5-\mathrm{C} 5$ & $126.82(17)$ & $C 9-C 10-C 10^{2}$ & $119.37\{1.6\}$ \\
\hline $\mathrm{C} 5-\mathrm{C} 6-\mathrm{C} 7$ & $122.60(17)$ & & \\
\hline
\end{tabular}

Symmetry codes: (i) $1-x, y, 1 / 2,-z$.

$(\mathrm{d}$, tienyl, $1 \mathrm{H}), \delta 7.40(\mathrm{~d}, \mathrm{HC}=, 1 \mathrm{H})$.

${ }^{13} \mathrm{C}-\mathrm{NMR}\left(\mathrm{CDCl}_{3}\right): \delta 115.00,117.75,117.95,128.95,129.94$, 132.12, 135.38, 137.17, 139.38, 177.76. Anal. calcd. for $\mathrm{C}_{13} \mathrm{H}_{14} \mathrm{~N}_{2} \mathrm{O}_{2} \mathrm{~S}$ : C, 59.54, H, 5.34, N, 10.68, S, 13.21\%. Found: C, 58.74, H, 5.15, N, 10.25, S, $13.18 \%$.

The crystallographic details are given in Table 1 . The structure was solved by direct methods and refined by least squares on $F_{\text {obs }}{ }^{2}$ by using the SIR97 and SHELXL97 programs, respectively. The $\mathrm{H}$ atoms of the hydroxyl and amino groups were found from a difference Fourier map and refined freely.
Table 4 Hydrogen-bonding geometry $\left(\AA,^{\circ}\right)$

\begin{tabular}{|c|c|c|c|c|}
\hline D-H...A & D-H & H...A & D...A & D-H...A \\
\hline $\mathrm{N} 1-\mathrm{H} 1 \mathrm{~A} \cdots \mathrm{O} 1^{i}$ & $0.96(2)$ & $2.00(2)$ & $2.955(3)$ & $174\{2\}$ \\
\hline $\mathrm{N} 1-\mathrm{H} 1 \mathrm{~B} \cdots \mathrm{O}^{1 i}$ & $0.71(2)$ & $2.35(2)$ & $3.019(3)$ & $157\{2\}$ \\
\hline 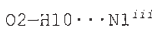 & $0.76(3)$ & $1.90\{3\}$ & $2.658(3)$ & $173\{3\}$ \\
\hline
\end{tabular}

Symmetry codes: (i) $1-x, 1+y, 1 / 2-z$; (ii) $x, 2-y,-1 / 2+z$; (iii) $1-x$, $2-y, 1-z$.

The other $\mathrm{H}$ atoms were positioned geometrically, with $\mathrm{C}-\mathrm{H}=$ $0.93 \AA$, and refined using a riding model, with $U_{\text {iso }}(\mathrm{H})=$ $1.2 U_{\text {eq }}(\mathrm{C})$.

The title molecule is shown in Fig. 2; the final atomic coordinates and the equivalent isotropic thermal parameters for non-hydrogen atoms are listed in Table 2, with selected bond lengths and bond angles listed in Tables 3. The molecule has a two-fold rotation axis located at the center of the benzene ring in the benzene-1,2-diamine moiety. In the crystal structure of the title compound, the bond lengths and angles are normal, ${ }^{4-6}$ with the exception of the bond lengths S1-C1 [1.686(3) $\AA$ ],

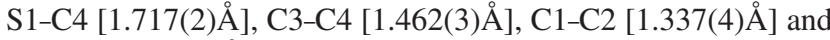
C2-C3 [1.447(4) $\AA]$. The benzene-1,2-diamine moity in the title compound has a rotation axis that passes through the mid point of the bonds $\mathrm{C} 8-\mathrm{C} 8 \mathrm{a}$ and $\mathrm{C} 10-\mathrm{C} 10 \mathrm{a}$.

The (2E)-3-(2-thienyl)arcylic acid and the benzene-1,2diamine moities are almost planar, with maximum deviations of $0.033(2),-0.027(2)$ and $-0.049(2) \AA$ for $\mathrm{O} 2, \mathrm{C} 3$ and $\mathrm{C} 6$ in the first moity, and $-0.013(2)$ and $0.014(2) \AA$ for $\mathrm{C} 10$ and N1 in the second moity, respectively. The dihedral angle between the planes of these two moities is $80.94(11)^{\circ}$. The crystal structure of title compound is stabilized by intermolecular $\mathrm{N}-\mathrm{H} \cdots \mathrm{O}$ and $\mathrm{O}-\mathrm{H} \cdot \cdots \mathrm{N}$ interactions; details are listed in Table 4.

\section{Acknowledgements}

The authors acknowledge the Faculty of Arts and Sciences, Ondokuz Mayis University, Turkey, for the use of the Stoe IPDS 2 diffractometer (purchased under grant F.279 of the University Research Fund). The authors, H. K. \& N. S3. also thank İnönü University Research Fund (BAPB-2005/36 and 2005/37) for financial support for this study.

\section{References}

1. A. K. Singh and J. W. Lown, Anti-Cancer Drug Des., 2000, 15, 265.

2. H. Küçükbay, R. Durmaz, N. Okuyucu, and S. Günal, Folia Micobiol., 2003, 48, 679.

3. H. Küçükbay, R. Durmaz, N. Okuyucu, S. Günal, and C. Kazaz, Arzneim.-Forsch./Drug Res., 2004, 54, 64.

4. M. Akkurt, S. Ö. Yıldırım, H Küçükbay, N. Şireci, and O. Büyükgüngör, Acta Cryst., 2006, E62, o3184.

5. M. Akkurt, S. Ö. Yıldırım, H. Küçükbay, Ü. Yılmaz, and O. Büyükgüngör, Acta Cryst., 2005, E61, o301.

6. S. Öztürk, M. Akkurt, H. Küçükbay, N. Okuyucu, and H. K. Fun, Acta Cryst., 2003, E59, o1014. 